\title{
65
}

\section{PENINGKATAN KESEJAHTERAAN PETANI DENGAN PENGUATAN KELOMPOK TANI}

\author{
Oleh: \\ Hafid Ramdhani, Soni Akhmad Nulhaqim, \& Muhammad Fedryansah
}

\begin{abstract}
ABSTRAK
Masyarakat miskin di pedesaan sebagian besar sebagai petani. Data BPS menunjukan masayarakat miskin pedesaan sebesar 18,48 juta orang pada tahun 2012.secara khusus perhatian terhadap petani perlu menjadi perhatian, karena berhubungan dengan masa depan usahatani padi dalam kesinambungan pruduksi petani sebagai makanan pokok Indonesia. program peningkatan produksi usaha tani selalu menajdi prioritas pemabangunan pertani dalam mensejahterakan petani. Dalam penguatan kelompok tani diperlukan upaya untuk meningkatkan kesejahteraan petani. Meskipun lemabaga kelompok tani telah banyak dibentuk, namun cukup sulit untuk saat ini menemukan kelompok tani yang aktif, dimana setiap anggota kelompok tani memanfaatkan lembaga tersebut untuk meningkatkan kinerja dalam usaha peningkatan kesejahteraan petani. Padahal kelompok tani memiliki peran dan fungsi yang sangat penting dalam menggerakan upaya pembangunan pertanian. Penguatan kelembagaan sangat perlu dilakukan melalui beberapa upaya, antara lain mendorong dan membimbing petani agar mampu bekerjasama di bidang ekonomi secara berkelompok, menumbuhkkembangkan kelompok tani melalui peningkatan fasilitas bantuan dan akses permodalan dan peningkatan efisiensi dan efektivitas petani, serta meingkatkan kapasitas sumber daya manusia petani melalui berbagai pendampingan, dan pelatihan untuk pengurus dan anggota. Secara teknis upaya peningkatan kelompok tani dalam pemberdayaan dilakukan oleh penyuluh pertanian lapangan (PPL). Meskipun demikian pendampingan pembinaan kelompok tani juga bisa dilakukan oleh LSM dan organisasi lainnya yang dianggap mampu untuk dilibatkan dalam usaha penguatan kelompok tani dalam pemberdayaan.
\end{abstract}

Key word : peran, fungsi, kelompok tani, penguatan.

\section{PENDAHULUAN}

Pembangunan pertanian pada dasarnya ditujukan bagi peningkatan kesejahteraan masyarakat terutama petani. Untuk itu dalam setiap tahapan kegiatan pembangunan pertanian kesejahteraan petani selalu menjadi tujuan. Dalam Rencana Strategis Kementerian Pertanian tahun 2010-2014 peningkatan kesejahteraan petani merupakan salah satu dari empat target utama pembangunan pertanian (Kementan, 2010).

Masyarakat miskin di perdesaan yang sebagian besar sebagai petani masih besar. Data BPS (2012) menunjukkan jumlah penduduk miskin di perdesaan yaitu berjumlah 18,48 juta jiwa atau 15,12 persen terhadap total penduduk perdesaan. Secara khusus perhatian terhadap kesejahteraan petani padi perlu menjadi perhatian, karena berkaitan dengan masa depan usahatani padi dalam kesinambungan produksi padi/beras sebagai makanan pokok masyarakat Indonesia. masalah-masalah yang dihadapi petani adalah dalam bidang pemasaran, keterampilan, pengetahuan, sumber daya dan motivasi. Dalam hal masalah penyelesaian masalah teresebut diperlukan suatu kelompok tani.

Kelompok tani adalah kelembagaan di tingkat petani yang dibentuk secara langsung oleh para petani secara terorganisir dalam usaha bertani. Kementrian pertanian disini mendefinisikan kelompok tani sebagai kumpulan petani/peternak/pekebun yang dibentuk atas dasar kesamaan kepentingan, 
kesamaan kondisi lingkungan (sosial, ekonomi, sumberdaya) dan keakraban untuk meningkatkan dan mengembangkan usaha para angotanya. Kelompok tani yang dibentuk oleh petani dan untuk petani, disini guna mengatasi masalah yang dialami oleh para petani serta menguatkan posisi petani, dalam memasarkan suatu produk pertanian.

Pada tahun 1968 dan tahun 1979 dibentuklah BIMAS program bimbingan masal yang dimana peran petani menunjukan hasil yang sangat signifikan. Bahkan didalam pembentukannya pun menjadi suatu kewajiban bagi para petani untuk membentuk suatu kelompok tani yang pada saat itu bukan kebutuhan para petani. Penyaluran usaha kredit petani program-program pemerintah untuk pertanian yang dimana disalurkan kepada para kelompok tani, karena dinilai ampuh dalam penyaluran dana. Konsekuensinya, semua desa harus membentuk kelompok tani agar mendapatkan fasilitas layanan pemerintah.semua petani secara tidak langsung menjadi sebagai anggota kelompok tani. Tidak mengherankan banyak dari petani yang tidak mengetahui bahwa mereka termasuk kedalam anggota kelompok apa dan ketua kelompok didalam kelompok tersebut.

Belakangan ini kelompok tani diperbesar menjadi suatu gabungan kelompok tani yang menjadi satu kawasan administratif (desa) atau yang dikenal dengan sebutan GAPOKTAN (gabungan kelompok tani). Berdasarkan Keputusan Mentri Pertanian No 93/ Kpts/OT.2103/3/1997 tentang pedoman Pembinaan Kelompok Tani-Nelayan "gabungan kelompok tani" adalah merupakan gabungan dari beberapa kelompok tani yang melakukan agribisnis diatas prinsip kebersamaan dan kemitraan sehingga mencapai peningkatan produksi dan pendapatan usaha tani bagi anggotanya dan petani lainya ( Syahyuti,2007). Oleh karena itu GAPOKTAN adalah sebuah wadah untuk kerjasama antar kelompok tani.

Alasan dibentuknya GAPOKTAN secara sudut pandang ekonomi adalah sebagai upaya dalam menghindari suatu biaya transaksi tinggi yang harus dikeluarkan oleh para anggotanya karena adanya masalah penumpang kepentingan komitmen dan loyalitas yang berbeda, serta faktor eksternal. Meskipun demikian paradigma suatu pembentukan gabungan kelompok tani ini belum tepat dikarenakan pembentukan kelompok tani ini hanya sebatas kelompok formal. Pada tahun 2006 jumlah kelompok tani tercatat 293.568 kelompok dan Gapoktan sebanyak 3000 ( Budi dan Aminah,2009)

Peningkatan kelompok tani dalam pemberdayaan tersebut belum diikuti dengan peningkatan kualitas sehingga maasih banyak kelompok tani yang belum mampu mandiri atau masih tetap ditentukan dari atas dalam berbagai hal seperti menentukan jenis suatu komoditas yang diusahakan, penentuan pasar,penentuan suatu mitra usaha, dan menentukan suatu harga komoditas dan sebagainya. Akibatnya, kualitas kelompok tani yang terbentuk tidak sesuai dengan peran aset komunitas masyarakat desa yang partisipatif, sehingga pengembangannya belum signifikan meningkatkan kapasitas masyarakat itu sendiri untuk menjadi mandiri di dalam upaya peningkatan kesejahteraan.

\section{PEMBAHASAN \\ Peran dan Fungsi Kelompok Tani}

Kelompok tani sebagai bagian dari peran dan fungsi dalam suatu penggerakan pemabangunan pertanian di dalam suatu desa tersebut. kelompok tani inilah yang menjadi pelaku utama didalam suatu pembangunan pertanian di suatu pedesaan. Dalam hal ini kelompok tani adalah sebagai wadah untuk membangun suatu pembangunan pertanian seperti peran penyediaan suatu modal, penyediaan informasi, serta pemasaran produk-produk petani ke pasaran.

Peran kelompok tani lebih kepada suatu gambaran mengenai kegiatan-kegiatan didalam kelompok tani yang dikelola oleh kesepakatan dari setiap anggota kelompok tani. Kegiatan yang berada didalam kelompok tani berdasarkan jenis usaha, atau unsur-unsur subsitem agribisnis, seperti didalam suatu pengadaaan sarana produksi, pemasaran, pengolahan dan sebagaianya. Pemilihan didalam suatu kelompok tani ini tergantung kepada suatu kesamaan kepentingan, saling percaya, dan 
keserasian didalam hubungan antar petani, sehingga bisa menjadi pengikat untuk lebih kuat dalam kelestarian kehidupan berkelompok, dimana tiap anggotanya menjadi lebih merasa memilki kelompok dan menikmati suatu manfaat didalam kelompok petani.

Peranan didalam suatu kelompok bisa dimainkan setiap waktu oleh pemimpin anggota maupun anggota didalam kelompok. pemimpin kelompok tani disini memiliki peran yang sangat penting didalam kelompok yaitu sebagai coordinator kelompok, dimana mereka yang menjelaskan atau menunujukan hubungan antara berbagai pendapat serta saran ,semenetara disisi lain setiap anggota berhak memainkan lebih dari satu peran dalam partisipasi kelompok. dilain hal pemimpin kelompok bisa menjadi suatu penggerak didalam bertindak atau mengambil keputusan dan berusaha untuk merangsang suatu kelompok agar tetap melakukan suatu kegiatan yang sudah ditentukan sebelumnya.

Meningkatnya suatu partisipasi kelompok akan memunculkan peningkatan kedinamisan kelompok. kedinamisan kelompok inilah yang akan membuat peluang sebesar-besarnya kepada anggota kelompok untuk bekerjasama dan berpartisipasi dalam memajukan suatu kelompok yang membuat tujuan yang dibuat tercapai. Kelompok tani yang dinamis ditandai dengan adanya interaksi didalam kelompok baik itu keluar maupun kedalam guna mencapai tujuan kelompok.

Sebagai suatu organisasi sosial kelompok tani adalah suatu wadah untuk belajar maupun mengajar bagi setiap anggotanya guna mendpatkan pengetahuan, keterampilan, dan sikap serta bertumbuh dan berkembanganya suatu kemandirian didalam berusahatani dengan suatu produktivitas yang meningkat, pendapatan yang bertambah dan kehidupan yang sejahtera.selain itu kelompok tani ini berfungsi sebagai suatu wahana kerjasama diantara petani dengan kelompok tani dan antar kelompok tani serta dengan pihak lain. Melalui suatu kerjasama ini diharapakan dapat membuat usaha taninya lebih efisien dan lebih mampu dalam menjawab suatu ancaman, tantang dan hambatan. Kelompok tani ini juga bisa berfungsi sebagai suatu unit produksi, yang dilaksanakan oleh setiap masing-masing anggota kelompok guna mencapai skala ekonomi yang lebih baik.

Pada saat ini kondisi sebagian besar kelompok tani dari tahun ke tahun dapat dikatakan belum mengalami suatu perkembangan seperti sesuatu yang diharapkan atau hanya berjalan di tempat bahkan sampai menurun. Gambaran dari kelompok tani tersebut seperti status didalam suatu keleasnya tingggi tetapi didalam kegiatanya rendah dan sebagian kelompok tani disini sudah bubar tetapi masih terdaftar.

Rendahnya suatu kinerja didalam kelompok tani antara lain disebabkan oleh kurangnya peran pengurus, anggota kelompok yang kurang jelas, struktur organisasi yang kurang lengkap dan tidak berfungsi, produktivitas usaha tani yang rendah, dan kurangnya pembinaan dari para penyuluh. Selain itu didalam pembentukan kelompok yang tidak secara partisipatif sehingga membuat tidak memuat potensi dan kepentingan petani, yang seharsunya menjadi modal untuk aksi kebersamaan. Bahkan kelompok tani sering dibentuk ketika ada pemberiaan modal usaha, pupuk bersubsidi dan bantuanbantuan lainya.

Umumnya kelompok tani yang sekarang ini dibentuk dari hasil proyek-proyekan sehingga ketika proyek sudah selasai maka kelompok tani ini pun bubar dan tidak berjalan. Namun adapaun kelompok tani yang maju walaupun sudah ditinggalkan oleh proyek maupun bantuan dari pemerintah. oleh sebab itu, upaya didalam peningkatan suatu kapsitas kelompok tani melalui berbagi pembinaan yang sangat penting untuk menjadi kelompok petani yang mandiri dan sejahtera.

Pembentukan dan penumbuhan suatu kelompok tani mestilah ditempatkan kedalam konteks yang lebih luas,yanitu kedalam konteks pengembangan ekonomi dan kemandirian masayarakat yang menuju pembangunan yang berkelanjutan.kelompok tani hanyalah suatu alat, dan merupakan salah satu opsi kelembagaan yang dipilih, bukan tujuan dan juga buka keharusan. Oleh karena, penggunaan suatu kelompok tani yang semata-mata hanya untuk mendapatkan bantuan ataupun modal dan bukan untuk pengembangan kelompok tani itu sendiri, maka yang terjadi adalah suatu kelompok tani yang hanya nama semata dan tidak ada eksistensi kelompok tani tersebut. 


\section{Penguatan kelompok tani}

Semakin besarnya suatu pembangunan pertanian di masa yang akan datang, terutama didalam mencapai yang namanya kesejahteraan petani, maka didalam kelembagaan kelompok tani yang diseluruh pedesaan Indonesia ini harus dibenahi dan diberdayakan, sehingga menjadi berdaya dalam kehidupan usaha taninya. Untuk mencapai hal keberdayaan tersebut, maka program pemberdayaan yang dilakukan harus bisa meningkatkan suatu kemampuan kelompok tani dalam hal memahami kekuataan dan potensi dan kelemahan kelompok, memperhitungkan peluang dan tantangan yang dihadapi, memilih alternatif yang ada dalam menyelesaikan masalah, dan menyelenggarakan suatu kehidupan berkelompok dan bermasayarakat yang serasi dengan lingkungannya.

Pada umumnya potensi suatu kelembagaan kelompok tani di dalam pedesaaan sangat besar dalam mendukung dan melasaknakan berbagai program pembangunan pertanian yang akan dilaksanakan karena itulah kelompok tani adalah dasar utama didalam pembangunan pertanian. Berdasarkan data yang diperoleh pada tahun 2006 akhir, jumlah kelompok tani mencapai sebesar 293.568 kelompok tani ( syahyutti, 2007). kelembagaan kelompok tani ini sangat penting untuk sarana kegiatan belajar,bekerja sama, dan pengumpulan modal didalam mengembangkan usahatani, jika pemberdayaan kelompok tani ini dilakukan dengan baik.

Pentingnya suatu pemberdayaan kelompok tani ini sangat beralasaan dikarenakan perhatian pemerintah saat ini sudah kurang semenjak otonomi daerah, dimana ada suatu kecenderungan perhatian pemerintah daerah yang sangat kurang terhadap kelembagaan kelompok tani, bahkan terkesan terabaikan sehingga kelembagaan kelompok tani ini yang sebenarnya adalah aset yang sangat berharga dalam suatu pembangunan pertanian menjadi tidak berfungsi secara optimal.

Apalagi saat ini masih banyak kelompok petani yang lupa modal dasar dalam suatu kelompok tani yaitu kekompakan dan tekad untuk mencapai suatu tujuan. Hal inilah yang membuat suatu kelompok pertanian berjalan. Jika tanpa tekad dan kekompakan maka yang terjadi adalah suatu kelompok yang berjalan tidak tahu arah dan tujuan. Saat ini kebanyakan kelompok tani lebih mementingkan mencari modal yang banyak, baik dengan iuran mupun dari dana pemerintah. Namun jika tanpa tekad dan kekompakan yang terjadi adalah kelompok tersebut hanyalah sebuah nama tanpa ada arti didalam kelompok tersebut yang membuat kelompok tersebut tidak akan aktif lagi. Oleh sebab itu, kekuatan utama didalam suatu kelompok bukan suatu modal tetapi suatu tekad dan kekompakan agar kelompok tersebut bisa menjadi lebih maju.

Menurut Kamus Besar Bahasa Indonesia tekad adalah kemauan (kehendak) yang pasti, kebulatan hati, iktikad. Dalam mencapai tujuan kelompok, kemauan yang kuat diantara setiap petani untuk berkembang perlu dimunculkan sebagai dasar dalam membangun sebuah kelembagaan petani yang efektif.

Selain tekad yang kuat, dibutuhkan pula suatu kekompakan. Kekompakan membutuhkan suatu syarat yang sangat tidak mudah. Salah satu persyaratanya adalah rasa percaya diatara setiap anggota dan kepercayaan anggota kepada pengurus kelompok tani. Untuk mewujudkan suatu kepercayaan diantara anggota dan pengurus diperlukan suatu tanggung jawab dan wibawa yaitu berupa laporan tiap bulan dari pengurus kepada kelompok agar mengikis yang namanya rasa curiga kepada pengurus kelompok tani.

Upaya dalam menumbuh kembangakan kelompok tani di Indonesia ini sudah berlangsung sejak zaman dahulu kala yaitu pada zaman Belanda. Dimana pada zaman orde baru, pengemabangan kelompok tani ini telah dilakukan dengan itensif yang membuat jumlah dari tahun ke tahun terus meningkat (Unang, 2009). Meskipun kelompok tani ini sudah banyak jumlahnya tetapi masih belum efektif untuk kepentingan para anggotanya.

Selama ini efektivitas didalam kelompok masih tergolong rendah. Hal tersebut disebakakn oleh masih terbatasnya peran kelompok tani, anggota yang tidak jelas, struktur organisasi tidak lengkap, produktivitas rendah dan pembentukan suatu kelembagaan pertanian yang tidak dilakukan 
dengan cara yang partisipatif sehinggga tidak dapat mengumpulkan potensi dan kepentingan petani, yang seharusnya menjadi modal utama dalam membangun kelembagaan petani dalam aksi kolektifnya. Bahkan di beberapa tempat yang terjadi adalah kelompok tani ini dibentuk saat-saat tertentu saja seperti dalam pemberian dana pemerintah, pemberian bantuan pupuk, dan bantuanbantuan lainya.

Walaupun keberadaan kelompok tani ini telah memberikan hasil yang sangat signifikan didalam membantu suatu pencapaian program pembangunan pertanian, namun paradigma didalam pembangunan kelompok tani ini masih belum tepat. Pembangunan kelompok tani yang dibuat oleh pemerintah cenderung membuat kelompok tani menjadi kelompok formal. Hal ini mengakibatkan kelompok tani yang semula bersifat kelompok sosial ( social group) menjadi kelopok tugas tau yang sering disebut Task Group, disini terlalu banyaknya intervensi dari luar terhadap kelompok tersebut.

Keberadaan suatu kelompk tani ini sangat penting untuk diberdayakan karena potensinya yang besar. Tetapi jika hanya disini mengandalakan tenaga penyuluh yang hanya sekitar puluhan ribuan sedangkan petani yang puluhan jutaan yang membuat para tenaga penyuluh ini tidak menggapai para petani dan tidak efektif dalam penyuluhan. Selain penyuluh yang kurang banyak jumlahnya disini penyuluh sendiri terbentur dengan kurangnya alat transportasi, sehingga mengakibatkan mobilitas yang kurang. Melihat dari berbagai masalah Sulit untuk berharap terwujudnya suatu kelompok tani yang penuh keterbatasan tersebut.

Secara umum ada tiga hal dalam menunjukan kekuataan suatu kelompok yaitu kemampuan kelompok tersebut dalam mecapai tujuan, kemampuan kelompok dalam mempertahanakan kelompoknya agar tetap kompak, kemampuan kelompok untuk berkembang dan berubah sehingga dapat terus meningkatkan suatu kinerja kelompok. kelompok yang berhasil adalah mempuanyai suatu kuliatas dan pola interkasi yang terintegrasi didalam kegiatan diatas ini ( Hermanto,2010)

Upaya didalam suatu peningkatan penguatan kelompok tani merupakan suatu hal yang tidak mudah, bahkan disini ini perlu memerlukan waktu yang sangat lama dan harus mempunyai finasial yang cukup. Namun demikian didalam penguatan kelompok tani ini memerlukan suatu kebijakan strategis dalam penguatan pemberdayaan kelompok tani yaitu diantaranya adalah :

1. Menciptakan suatu iklim yang kondusif didalam lingkungan kelompok tani seperti menumbuhkan rasa kepercayaan kepada setiap kelompoknya.

2. Menumbuhkembangkan suatu kreativitas dan prkarsa anggota kelompok tani agar memanfaatkan peluang usaha, informasi dan akses suatu permodalan yang tersedia.

3. Membantu memperlancar proses dalam mengidentifikasi suatu masalah serta menyusun dan memecahkan masalah yang dihadapi dalam usahataninya.

4. Meningkatkan kemampuan dalam mengetahui potensi pasar dan peluang usaha serta menganalisis potensi yang dimiliki agar bisa mengembangkan usahatani yang lebih besar.

5. Meningkatkan kemampuan dalam menganalisis potensi usaha masing-masing anggota agar menjadi satu unit usaha yang mampu menjamin permintaan pasar.

6. Mendorong dan mengadvokasi agar para petani mau dan mampu melaksanakan kegiatan simpan pinjam dalam memfasilitasi pengembangan modal usaha.

Dalam menginplematasikan strategi tersebut perlu dilakukan upaya agar stratergi tersebut bisa berjalan diantaranya adalah:

1. mendorong dan membibimbing petani agar mampu bekerjasama di bidang ekonomi secara kelompok.

2. menumbuhkembangkan Kelompok tani melalui peningkatan akses permodalan bagi petani,peningkatan posisi tawar,pembinaan kepada organisasi kelompok, serta peningkatan efisiensi dan efektivitas usahatani.

3. meingkatkan kapasitas SDM petani melalui berbagai kegiatan pendampingan, dan pelatihan yang dirancang secara khsusus bagi pengurus dan anggota kelompok tani. 
Didalam upaya penguatan pemberdayaan kelompok tani ini, secara teknis dilakukan oleh penyuluh pertanian. Meskipun demikian pendampingan pembinaan kelompok tani ini bisa dilkukan oleh LSM, dan organisasi lainya yang dianggap mampu dan berpengalaman didalam suatu pemngembangan pemberdayaan masyarakat. dalam hal ini adalah tugas pendamping adalah mengemabngkan suatu sikap partisipasi, sikap, pengetahuan dan keterampilan kelompok tani dan anggotanya dalam mencapai suatu tujuan bersama.

\section{KESIMPULAN}

Demikian banyak kelompok tani yang dibentuk, namun sebagian besar kinerjanya masih belum bisa diharapkan. Keberadaan kelompok tani yang umumnya dicirikan antara lain: (1) kelompok yang tidak mandiri, (2) partisipasi anggota yang kurang, (3) sebagian kelompok tani yang belum kompak dan sebagian lagi sudah bubar namun masih terdaftar. Meskipun demikian peranan dan fungsi kelompok tani dapat ditingkatkan dengan menumbuhkembangkan kekuatan-kekuatan yang dimiliki dalam kelompok tani itu sendiri agar dapat menggerakan dan mendorong perilaku anggotanya ke arah pencapaian tujuan kelompok. oleh karena itu, upaya penguatan pemberdayaan kelompok tani merupakan langkah strategis yang sangat penting untuk dilakukan dalam upaya meningkatkan kesejahteraan petani.

Langkah-lagkah yang dapat dilakukan dalam upaya penguatan kelompok tani, antara lain mendorong dan membibimbing petani agar mampu bekerjasama di bidang ekonomi secara kelompok, menumbuhkembangkan kelompok tani melalui peningkatan akses permodalan bagi petani,peningkatan posisi tawar,pembinaan kepada organisasi kelompok, serta peningkatan efisiensi dan efektivitas usahatani, serta meingkatkan kapasitas SDM petani melalui berbagai kegiatan pendampingan, dan pelatihan yang dirancang secara khsusus bagi pengurus dan anggota kelompok tani.

\section{Daftar Pustaka}

Budimanta, Arif. 2004. Corporate Sosial Responsibility. Jakarta : Indonesia Center for Sustainable Development (ICSD)

Tanaya, Jimmy. 2004. Tanggung Jawab Sosial Korporasi.Surakarta : BWI.

Suharto,Edi.1997.Pembangunan Kebijakan dan Pekerjaan Sosial Spektrum Pemikiran Bandung : SpSTKS

Koentjaningrat.1997. Metode-Metode Penelitian Masyarakat. Jakarta : Gramedia

Sekarningsih, Renny 1991. Pengantar Pekerjaan Sosial. Bandung: UNPAD

Hikmat, Harry.2004. Strategi pemberdayaan masyarakat. Bandung : Humaira

Suharto, Edi.2005. Membangun Masyarakat Memberdayakan Rakyat. Bandung : Mitra anda

Saptana.10 September 2011. Konsep efiseinesi usaha tani pangan dan Implikasinya bagi peningkatan produktivitas.Pusat Sosial Ekonomi dan Kebijakan Pertanian Badan Penelitian dan Pengembagan Pertanian Kementrian Pertanian. Forum Agro Ekonomi Vol. 30 No. 22012

Rachmat Muchjidin dan Tjetjep Nurasa. 29 Agustus 2013.Nilai tukar petani padi di beberapa sentra produksi padi di Indonesia. Pusat Sosial Ekonomi dan Kebijakan Pertanian Badan Penelitian dan Pengembagan Pertanian Kementrian Pertanian.Jurnal Agro Ekonomi Vol. 31 No. 02 2013 
Ariani Mewa ,Basuno Edi,Purwantini Bastuti Tri dan Yusdja Yusmichad. 1 Mei 2004. Analisis peluang peningkatan kesempatan kerja dan pendapatan petani melalui pengelolaan usaha tani bersama. Pusat Sosial Ekonomi dan Kebijakan Pertanian Badan Penelitian dan Pengembagan Pertanian Kementrian Pertanian. Jurnal Agro Ekonomu Vol. 22 No. 12014.

Soetomo. 2006. Strategi-Strategi Pembangunan Masyarakat.Yogyakarta: Pustaka Pelajar.

Rudito, Bambang dkk. 2003. Akses Peran Masyarakat "Lebih Jauh Memahami Community Develompment". Jakarta : ICSD

Suharto, Edi. 2010. Membangun Masyarakat Memberdayakan Masyarakat "Kajian Strategis Pembangunan Kesejahteraan Sosial dan Pekerjaan Sosial. Bandung : Refika Aditama.

Wahyudiyana, Singgih. 2001. Strategi pendampingan dalam pemberdayaan komunitas petani :Kajian terhadap pemberdayaan komunitas petani melalui kegiatan pendampingan sosial yang dilaksanakan sekretariat Bina Desa /INDHRRA Jakarta: Studi kasus pendampingan sosial komunitas petani di desa 